\title{
SISTEM PENDUKUNG KEPUTUSAN PEMILIHAN LOKASI PERUMAHAN MENGGUNAKAN METODE PROFILE MATCHING
}

\author{
Zulfan Efendi \\ Sistem Informasi,STMIK Royal Kisaran \\ email: zulfan808@gmail.com
}

\begin{abstract}
In the business of property developers choosing a location to be an important decision for developers as a factor of attractiveness in housing marketing, if lack of observance in choosing the location of the location will result in slow sales, so that the company's profits become not optimal. For this reason, a decision support system is needed that can help developers in recommending housing locations that are in accordance with the wishes of the developer. The profile matching method is chosen because it can provide the closest value recommendation, so if there is no land the exact location in accordance with the wishes of the developer but the profile maching is able to provide the selection of the location with the closest profile value to the developer desired.
\end{abstract}

Keywords: Decision support system, Developer, Property, Location Land, Profile matching.

\begin{abstract}
Abstrak: Lokasi merupakan faktor terpenting dalam usaha developer property, karena mempengaruhi tingkat pemasaran perumahan. Pemilihan lokasi menjadi keputusan penting, sehingga dibutuhkan suatu sistem pendukung keputusan yang tepat. Metode profile matching merupakan pilihan yang dapat memberikan rekomendasi. Hasil dari penelitian ini adalah memberikan rekomendasi dengan nilai terdekat, jadi walaupun tidak ada lahan lokasi yang sesuai persis keinginan developer tapi profile matching akan memberikan rekomendasi pemilihan lahan lokasi dengan profil yang terdekat sesuai harapan developer. Maka, dapat disimpulkan profile matching merupakan pilihan tepat dalam penentuan keputusan lokasi perumahan.
\end{abstract}

Kata kunci: Sistem pendukung keputusan, Developer, Property, Lahan Lokasi, Profile matching.

\section{PENDAHULUAN}

Perkembangan teknologi informasi dan komunikasi juga diterapkan di berbagai bidang salah satunya dibidang ekonomi. Property merupakan salah satu sektor ekonomi yang mulai berkembang, hal ini dikerenakan rumah adalah kebutuhan primer untuk sebuah keluarga, dimana rumah merupakan tempat untuk berteduh dari matahari atau hujan. Salain itu rumah juga sering dijadikan objek investasi karena rumah memiliki nilai investasi yang bagus [1]. Property disini yaitu mengembangkan atau membangun perumahan. Dalam usaha developer property memilih lokasi menjadi keputusan penting bagi developer sebagai faktor daya tarik dalam pemasaran perumahan. apabila kurang jeli dalam 
memilih lahan lokasi perumahan akan berakibat lambatnya penjualan, sehingga keuntungan perusahaan menjadi tidak optimal. Untuk itu dibutukan sebuah sistem yang dapat membantu dalam pemilihan lokasi lahan perumahan yang akan dibangun perumahan. Sistem pendukung keputusan (SPK) adalah gabungan kumpulan kemampuan manusia dengan teknologi komputer untuk melakukan pengolahan data dan keputusan yang dapat dijadikan dalam membantu seorang menejer dalam mengambil keputusan saat menghadapi permasalahan semi terstruktur [2]. SPK dapat memberikan alternatif solusi dalam menentukan keputusan yang tepat dan sesuai, dengan menggunakan data atau model untuk membantu menangani berbagai masalah yang terstruktur maupun tidak terstruktur [3]. Ada banyak metode yang dapat digunakan pada pengambilan keputusan, yaitu Profile matching (PM) yang memberikan solusi serta memiliki tujuan yang jelas secara objektif pada pengambilan keputusan [4]. Dengan metode PM tersebut dapat memberikan solusi yang lebih handal [5]. Dengan kriteria yang telah ditentukan sesuai dengan kebutuhan serta alternatif yang dipilih sebagai acuan dalam pemilihan lokasi perumahan. Metode profile matching ini mampu memberikan rekomendasi dengan nilai terdekat, jadi walaupun tidak ada lahan lokasi yang sesuai persis keinginan developer tapi profile matching akan memberikan rekomendasi pemilihan lahan lokasi dengan profil yang terdekat sesuai harapan developer. Tujuan pada penelitian ini adalah Dengan adanya sistem keputusan menggunakan Metode profile matching dapat membantu developer dalam pemilihan lokasi untuk pembangunan perumahan.

\section{METODE}

Metodologi merupakan jabaran setiap kegiatan dalam pengembangan sistem yang dilakukan sesuai dengan tahapan-tahapan pada metode yang digunakan serta implemantasi sistem dapat dilakukan sesuai dengan kerangka kerja penelitian.

Adapun kerangka kerja tersebut dapat divisualisasikan pada gambar berikut ini:

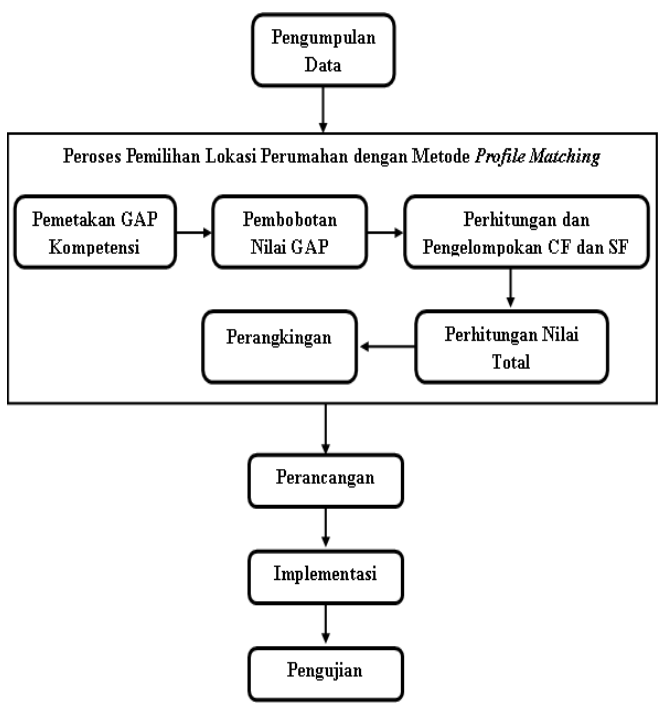

Gambar 1. Tahapan Proses Penelitian

Pada Gambar 1 menunjukkan alur proses dari sistem pendukung keputusan pemilihan lokasi perumahan dengan menggunakan metode profile matching.

\section{Pengumpulan Data}

Pada tahap ini dilakuan proses pengumpulan data dengan cara meminta langsung kepada pimpinan kantor pemasaran PT. Wahyu Asri. Data yang didapatkan untuk penelitian ini berupa site plan perumahan dan fotocopy lembaran sertifikat tanah perumahan. Dalam Penelitian ini digunakan teknik penelitian kuantitatif dengan tipe deskriptif yang dilakukan dengan 
DOI: https://doi.org/10.33330/jurteksi.v6i1.408

Available online at http://jurnal.stmikroyal.ac.id/index.php/jurteksi

menentukan aspek kriteria.

\section{Analisa metode profile matching}

Setelah data dikumpulkan, akan dilakukan penganalisaan data untuk menyesuaikan kegiatan data yang akan diolah pada metode profile matching pada pemilihan lokasi perumahan. Adapun langkah-langkah dalam metode profile matching sebagai berikut:

1. Pemetakan GAP Kompetensi

Pemetakan GAP pada bahasan ini ialah menghitung perbedaan nilai gap untuk masing-masing kriteria yang dimiliki oleh setiap lokasi perumahan. Peroses yang dilakukan pada penilaian gap adalah dengan menentukan perbedaan atau selisih antara profil lokasi dengan profil pencapaian yang merupakan acuan dalam pemilihan lahan lokasi kriteria yang diinginkan developer sesuai dengan nilai aspek yang ada.

2. Pembobotan Nilai GAP

Setelah pemetakan GAP dilakukan dari masing-masing lokasi, maka hasil dari pemetakan tersebut diberi bobot nilai dengan acuan seperti ditunjukkan pada Tabel 1

Tabel 1. Pembobotan Nilai GAP

\begin{tabular}{cccl}
\hline No & Selisih & Bobot Nilai & \multicolumn{1}{c}{ Keterangan } \\
\hline 1 & 0 & 5 & Kompetensi sesuai dengan yang dibutuhkan \\
\hline 2 & 1 & 4.5 & Kompetensi lokasi kelebihan 1 tingkat/level \\
\hline 3 & -1 & 4 & Kompetensi lokasi kekurangan 1 tingkat/level \\
\hline 4 & 2 & 3.5 & Kompetensi lokasi kelebihan 2 tingkat/level \\
\hline 5 & -2 & 3 & Kompetensi lokasi kekurangan 2 tingkat/level \\
\hline 6 & 3 & 2.5 & Kompetensi lokasi Kelebihan 3 tingkat/level \\
\hline 7 & -3 & 2 & Kompetensi lokasi kekurangan 3 tingkat/level \\
\hline 8 & 4 & 1.5 & Kompetensi lokasi kelebihan 4 tingkat/level \\
\hline 9 & -4 & 1 & Kompetensi lokasi kekurangan 4 tingkat/level \\
\hline
\end{tabular}

Pada Tabel 1 Ini digunakan untuk acuan pembobotan nilai gap.

3. Perhitungan dan pengelompokan Core Factor dan Scondary Factor

Setelah seluruh bobot nilai diperoleh, maka proses berikutnya adalah perhitungan nilai Core factor dan Secondary factor.

- Core factor merupakan aspek (kompetensi) yang paling menonjol atau paling dibutuhkan. Rumus perhitungan Core factor adalah sebagai berikut:

$$
N C F=\frac{\sum N C}{\sum I C}
$$

Dimana:

NCF : Nilai rata-rata core factor

NC : Jumlah total nilai core factor

IC : Jumlah item core factor

- Scondary Factor merupakan faktor pendukung dari faktor utama. Rumus perhitungan Scondary Factor adalah sebagai berikut:

$$
N C F=\frac{\sum N S}{\sum I S}
$$


DOI: https://doi.org/10.33330/jurteksi.v6i1.408

Available online at http://jurnal.stmikroyal.ac.id/index.php/jurteksi

Dimana:

NSF : Nilai rata-rata secondary factor

NS : Jumlah total nilai core factor

IS : Jumlah item secondary factor

\section{Perhitungan Nilai Total}

Perhitungan nilai total berdasarkan persentase core factor dan secondary factor, yang diperkirakan berpengaruh pada masing-masing profile. Adapun rumus untuk menghitung nilai total ini adalah sebagi berikut:

$$
N T=(X) \% N C I+(X) \% N I S
$$

Dimana:

N : Nilai Total Masing-masingAspek

NCI : Nilai CF

NSI : Nilai SF

(X) $\%$ : Nilai Presentase

$\mathrm{N}$ : Nilai Total

5. Perengkingan

Adapun hasil akhir untuk proses perhitungan metode Profile matching ialah melakukan perangkingan dari setiap kandidat yang diajukan. Rumus untuk melakukan perangkingan adalah sebagai berikut:

Rangking $=(X) \% \mathrm{~N} 1+(X) \% \mathrm{Na}=\mathrm{Na}$

Dimana:

N1 : Nilai rata-rata aspek 1

$\mathrm{Nn}$ : Nilai rata-rata aspek lainnya

$\mathrm{Na}$ : Nilai

Total

Akhir

Perangkingan

\section{HASIL DAN PEMBAHASAN}

Adapun langkah-langkah yang dilakukan pada metode PM untuk pemilihan lokasi perumahan, setiap lokasi dikodekan, seperti terlihat pada Tabel 2.
Tabel 2. Data Lokasi

\begin{tabular}{ccl}
\hline No & $\begin{array}{c}\text { Kode } \\
\text { Lokasi }\end{array}$ & \multicolumn{1}{c}{ Alamat Lokasi } \\
\hline 1 & LK001 & $\begin{array}{l}\text { Jl. Abu Samah Rt.01 } \\
\text { Kel. Mutiara }\end{array}$ \\
\hline 2 & LK002 & $\begin{array}{l}\text { Jl. Bawang Kel. } \\
\text { Siumbut Baru }\end{array}$ \\
\hline 3 & LK003 & $\begin{array}{l}\text { Jl. Arcis Lk.III Kel. } \\
\text { Siumbut Umbut }\end{array}$ \\
\hline 4 & LK004 & $\begin{array}{l}\text { Jl. Paria Kel Siumbut } \\
\text { Baru }\end{array}$ \\
\hline 5 & LK005 & $\begin{array}{l}\text { Jl. Mentimun Siumbut } \\
\text { Baru }\end{array}$ \\
\hline 6 & LK006 & $\begin{array}{l}\text { Jl. Rimbang Siumbut } \\
\text { Baru }\end{array}$ \\
\hline
\end{tabular}

Data dari Tabel 2 diolah untuk menentukan aspek kriteria. penkodean aspek penelitian dapat dilihat pada Tabel 3 dan 4.

Tabel 3. Aspek Khusus

\begin{tabular}{ccl}
\hline No & Code & \multicolumn{1}{c}{ Subkriteria } \\
\hline 1 & C1 & Usia Sertifikat \\
\hline 2 & C2 & $\begin{array}{l}\text { Jenis Pembayaran } \\
\text { Lahan }\end{array}$ \\
\hline 3 & C3 & Akses Jalan Kelokasi \\
\hline \multicolumn{3}{c}{ Tabel } \\
& 4. Aspek Umum \\
\hline No & Code & \multicolumn{1}{c}{ Subkriteria } \\
\hline 1 & C4 & Jenis Jalan Masuk \\
\hline 2 & C5 & $\begin{array}{l}\text { Jarak Rumah Sakit } \\
\text { atau Puskesmas }\end{array}$ \\
\hline 3 & C6 & Jarak Pasar atau Mall \\
\hline 4 & C7 & $\begin{array}{l}\text { Jarak Sekolah atau } \\
\text { Kampus }\end{array}$ \\
\hline
\end{tabular}

Data dari Tabel 2 sampai dengan data Tabel 4 digabungkan untuk pengisian nilai dari setiap aspek yang telah didapat dari sumber penelitian. Pengisian nilai ini dapat dilihat pada Tabel 5. 
Tabel 5. Nilai Aspek

\begin{tabular}{ccccccccc}
\hline \multirow{2}{*}{ No } & Kode & \multicolumn{3}{c}{ Aspek Khusus } & \multicolumn{4}{c}{ Aspek Umum } \\
\cline { 3 - 9 } & Lokasi & C1 & C2 & C3 & C4 & C5 & C6 & C7 \\
\hline 1 & LK001 & 4 & 3 & 3 & 4 & 4 & 3 & 4 \\
\hline 2 & LK002 & 3 & 1 & 2 & 4 & 3 & 2 & 3 \\
\hline 3 & LK003 & 4 & 2 & 3 & 3 & 2 & 4 & 3 \\
\hline 4 & LK004 & 4 & 2 & 3 & 4 & 3 & 4 & 4 \\
\hline 5 & LK005 & 1 & 1 & 3 & 3 & 1 & 4 & 3 \\
\hline 6 & LK006 & 2 & 3 & 2 & 2 & 3 & 4 & 3 \\
\hline
\end{tabular}

Tahapan selanjutnya yaitu penetapan GAP dari masing-masing aspek. Data
GAP tersebut dapat dilihat pada Tabel 6 dan 7.

Tabel 6. Pemetakan Gap

\begin{tabular}{ccccccccc}
\hline \multirow{2}{*}{ No } & $\begin{array}{c}\text { Kode } \\
\text { Lokasi }\end{array}$ & \multicolumn{3}{c}{ Aspek Khusus } & \multicolumn{5}{c}{ Aspek Umum } \\
\cline { 2 - 9 } Nilai Bobot & & C1 & C2 & C3 & C4 & C5 & C6 & C7 \\
\hline 1 & LK001 & 4 & 3 & 3 & 4 & 4 & 3 & 4 \\
\hline 2 & LK002 & 3 & 1 & 2 & 4 & 3 & 2 & 3 \\
\hline 3 & LK003 & 4 & 2 & 3 & 3 & 2 & 4 & 3 \\
\hline 4 & LK004 & 4 & 2 & 3 & 4 & 3 & 4 & 4 \\
\hline 5 & LK005 & 1 & 1 & 3 & 3 & 1 & 4 & 3 \\
\hline 6 & LK006 & 2 & 3 & 2 & 2 & 3 & 4 & 3 \\
\hline
\end{tabular}

Tabel 7. Pemetakan Nilai Gap

\begin{tabular}{ccccccccc}
\hline \multirow{2}{*}{\begin{tabular}{c} 
Profil \\
\multicolumn{2}{c}{ Pencapaian }
\end{tabular}} & \multicolumn{4}{c}{ Aspek Khusus } & \multicolumn{5}{c}{ Aspek Umum } \\
\hline 1 & LK001 & 0 & 0 & $\mathbf{3}$ & $\mathbf{4}$ & $\mathbf{4}$ & $\mathbf{4}$ & $\mathbf{4}$ \\
\hline 2 & LK002 & -1 & -2 & -1 & 0 & -1 & -2 & -1 \\
\hline 3 & LK003 & 0 & -1 & 0 & -1 & -2 & 0 & -1 \\
\hline 4 & LK004 & 0 & -1 & 0 & 0 & -1 & 0 & 0 \\
\hline 5 & LK005 & -3 & -2 & 0 & -1 & -3 & 0 & -1 \\
\hline 6 & LK006 & -2 & 0 & -1 & -2 & -1 & 0 & -1 \\
\hline
\end{tabular}

Tahap selanjutnya adalah menetapkan bobobt nilai GAP kompetensi dari setiap lokasi seperti ditunjukan Tabel 8. 
Tabel 8. Hasil Pemetakan Gap Kompetensi

\begin{tabular}{|c|c|c|c|c|c|c|c|c|c|}
\hline \multirow{2}{*}{ No } & \multirow{2}{*}{$\begin{array}{l}\text { Kode } \\
\text { Lokasi }\end{array}$} & \multicolumn{3}{|c|}{ Aspek Khusus } & \multicolumn{4}{|c|}{ Aspek Umum } & \multirow{9}{*}{$\begin{array}{c}\text { Bobot } \\
\text { Nilai } \\
\text { GAP }\end{array}$} \\
\hline & & C1 & $\mathrm{C2}$ & $\mathrm{C3}$ & $\mathrm{C4}$ & $\mathrm{C5}$ & C6 & C7 & \\
\hline \multicolumn{9}{|c|}{ Nilai Bobot } & \\
\hline 1 & LK001 & 5 & 5 & 5 & 5 & 5 & 4 & 5 & \\
\hline 2 & LK002 & 4 & 3 & 4 & 5 & 4 & 3 & 4 & \\
\hline 3 & LK003 & 5 & 4 & 5 & 4 & 3 & 5 & 4 & \\
\hline 4 & LK004 & 5 & 4 & 5 & 5 & 4 & 5 & 5 & \\
\hline 5 & LK005 & 2 & 3 & 5 & 4 & 2 & 5 & 4 & \\
\hline 6 & LK006 & 3 & 5 & 4 & 3 & 4 & 5 & 4 & \\
\hline
\end{tabular}

Setelah menentukan bobot nilai GAP untuk kedua aspek, maka aspek dikelompokan menjadi 2 kelompok yaitu
CF dan SF. Nilai CF dan SF dapat dilihat pada Tabel 9.

Tabel 9. Hasil Pemetakan Gap Kompetensi

\begin{tabular}{|c|c|c|c|c|c|c|c|c|c|c|}
\hline \multirow{2}{*}{ No } & \multirow{2}{*}{$\begin{array}{c}\text { Kode } \\
\text { Lokasi } \\
\end{array}$} & \multicolumn{3}{|c|}{ Aspek Khusus } & \multicolumn{6}{|c|}{ Aspek Umum } \\
\hline & & $\mathbf{C F}$ & $\mathbf{C F}$ & $\mathbf{C F}$ & TOT & SF & SF & SF & SF & TOT \\
\hline 1 & LK001 & 5 & 5 & 5 & 5,0 & 5 & 5 & 4 & 5 & 4,8 \\
\hline 2 & LK002 & 4 & 3 & 4 & 3,7 & 5 & 4 & 3 & 4 & 4,0 \\
\hline 3 & LK003 & 5 & 4 & 5 & 4,7 & 4 & 3 & 5 & 4 & 4,0 \\
\hline 4 & LK004 & 5 & 4 & 5 & 4,7 & 5 & 4 & 5 & 5 & 4,8 \\
\hline 5 & LK005 & 2 & 3 & 5 & 3,3 & 4 & 2 & 5 & 4 & 3,8 \\
\hline 6 & LK006 & 3 & 5 & 4 & 4,0 & 3 & 4 & 5 & 4 & 4,0 \\
\hline
\end{tabular}

Langkah berikutnya adalah perhitungan Perhitungan presentase nilai khusus nilai total. Nilai total dihitung adalah $60 \%$ dan nilai umum adalah $40 \%$. berdasarkan presentase dari CF dan SF Seperti ditunjukkan Tabel 10. yang diperkirakan paling berpengaruh.

Tabel 10. Hasil Akhir Proses Profile matching

\begin{tabular}{cccccc}
\hline \multirow{2}{*}{ No } & $\begin{array}{c}\text { Kode } \\
\text { Lokasi }\end{array}$ & Aspek Khusu & Aspek Umum & Total & \multirow{2}{*}{ Rank } \\
\cline { 3 - 4 } & Total Nilai CF & Total Nilai SF & & \\
\hline 1 & LK001 & 5,0 & 4,8 & 4,92 & 1 \\
\hline 2 & LK002 & 3,7 & 4,0 & 3,82 & 5 \\
\hline 3 & LK003 & 4,7 & 4,0 & 4,42 & 3 \\
\hline 4 & LK004 & 4,7 & 4,8 & 4,74 & 2 \\
\hline 5 & LK005 & 3,3 & 3,8 & 3,50 & 6 \\
\hline 6 & LK006 & 4,0 & 4,0 & 4,00 & 4 \\
\hline
\end{tabular}


Available online at http://jurnal.stmikroyal.ac.id/index.php/jurteksi

Setiap lokasi mendapatkan nilai akhir. Dari nilai akhir tersebut dilakukan perangkingan lokasi. Semakin tinggi nilai pada hasil akhir maka semakin besar pula kesempatan untuk dipilih sebagai lokasi untuk dibangun perumahan. Dari Tabel 9 diatas, maka didapat nilai rangking tertinggi adalah lokasi dengan kode LK001 yaitu dengan nilai akhir sama dengan 4,92 .

\section{PENGUJIAN SISTEM}

Langkah awal dalam pengujian sistem ini adalah dengan meng_input_kan data setiap lokasi lahan yang diperoleh dari PT. Wahyu Asri Kisaran, yang nantinya akan dipilih sebagai lokasi untuk dibangun perumahan, seperti pada gambar dibawah ini:

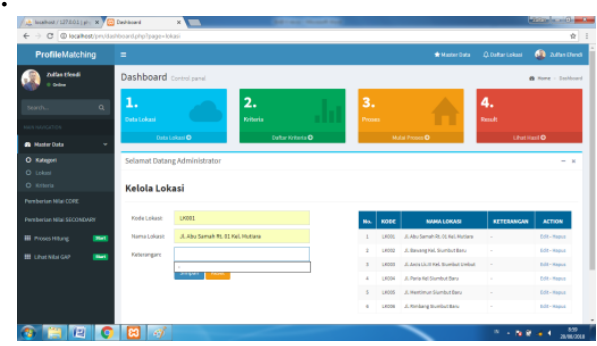

Gambar 2. Form Kelola Lokasi

Pada Gambar 2 dapat dijelaskan bahwa untuk kolom kode lokasi diisikan dengan kode yang diinisialkan, untuk kolom nama lokasi diisikan dengan alamat lengkap lokasi lahan, dan untuk kolom keterangan diisikan keterangan jika diinginkan.

Langkah selanjutnya setelah input data lokasi adalah proses kelola kriteria, yang mana pada tahapan ini untuk setiap lahan lokasi memiliki beberapa kriteria yang akan dinilai. Dan untuk setiap kriteria akan digolongkan kedalam nilai core factor atau secondary factor agara dalam proses perhitungan dapat dilakukan. Seperti gambar dibawah ini:

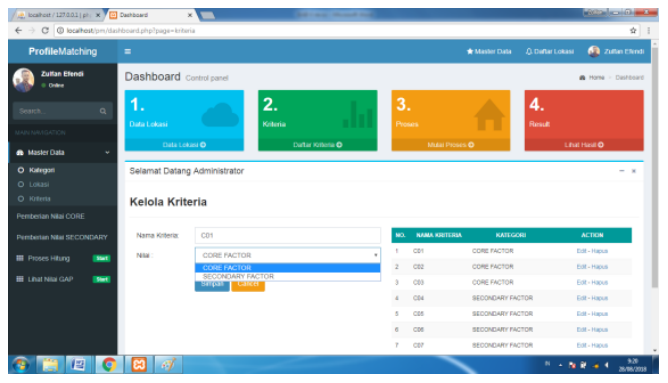

Gambar 3. Form Kelola Kriteria

Pada Gambar 3 dapat dilihat terdapat kolom nama kriteria yang di isikan dengan kode C01 sebagai kriteria usia sertifikat, dan pada kolom nilai dipilih sebagai Core Factor, atau secondary factor, klik menu simpan untuk menyimpan data hingga mincul pada tabel kriteria. Peroses terus dilakukan sampai seluruh kriteria lokasi diinputkan.

Langkah selanjutnya adalah memberikan nilai setiap masing-masing kriteria yang dimiliki lokasi, adapun gambarannya dapat dilihat dibawah ini:

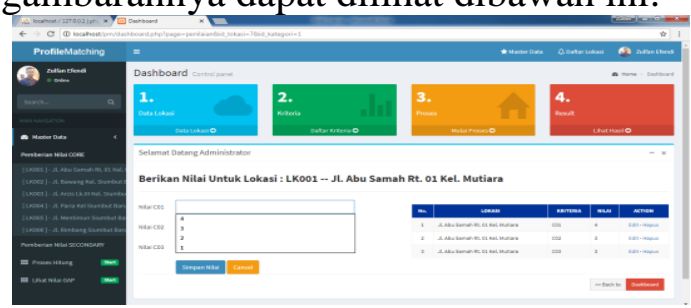

Gambar 4. Form Kelola Nilai Kriteria

Langkah selanjutnya adalah pemberian nilai persentasi kategori yaitu persentasi nilai core factor dan persentase nilai secondary factor. adapun hasilnya tampak pada gambar dibawah ini:

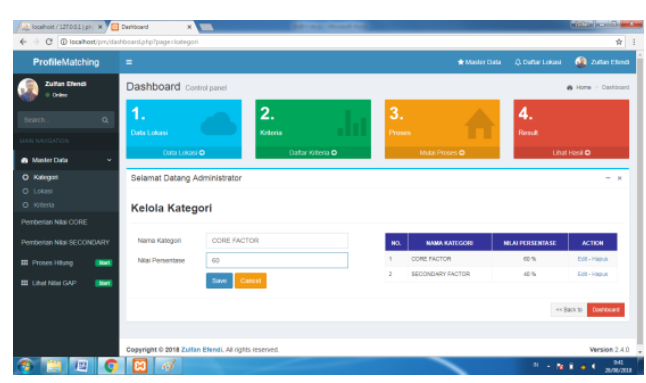

Gambar 5. Form Kelola Kategori 
Pada Gambar 5 dapat dijelaskan pada kolom nama kategori disikan Core Factor dan nilai persentasi diberikan sebesar $60 \%$ lalu data disimpan, selanjutnya untuk Secondary Factor di berikan nilai persentasi sebesar $40 \%$. Selanjutnya tahap peroses perhitungan dengan cara mengklik menu Proses Hitung, maka akan muncul hasil nilai setiap lokasi.

Setelah seluruah tahap rangkaian proses dilakukan, maka untuk melihat hasil dari sistem dapat dilakukan dengan cara meng-klik menu Lihat Hasil, adapun hasilnya seperti gambar berikut ini:

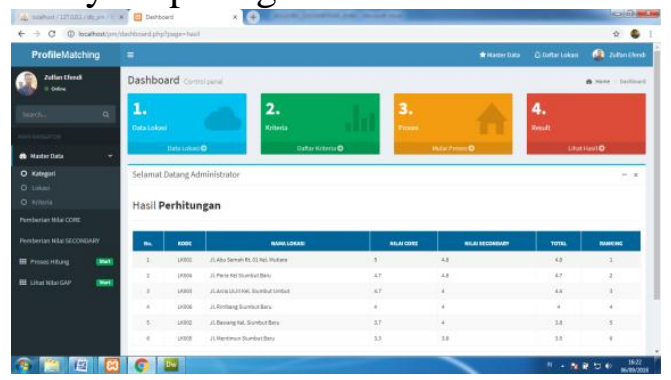

Gambar 6. Form Hasil Perhitungan

Setelah dilakukan proses pengujian menggunakan aplikasi SPK dengan metode profile matching ditunjukkan pada Gambar 6, maka hasil tersebut dibandingkan dengan hasil perhitungan manual seperti pada Tabel 10 diatas.

\section{SIMPULAN}

Berdasarkan uraian pembahasan diatas, maka dapat diambil kesimpulan dan saran sebagai berikut:

Metode Profile matching dapat membantu develover untuk memberikan rekomendasi lokasi perumahan yang akan dibangun. Untuk penelitian selanjutnya agar ditambahkan kriteria yang lainnya, sehingga mendapatkan hasil yang lebih baik dan optimal.

\section{DAFTAR PUSTAKA}

[1] Rais, M. S. (2016). Sistem Pendukung Keputusan Untuk Pemilihan Lokasi Perumahan Menggunakan Analytical Hierarchy Process ( AHP ). Riau Journal Of Computer Science, 2(2), 59-72.

[2] Ananta, Widara, P., \& Winiarti, S. (2013). Sistem Pendukung Keputusan Dalam Penilaian Kinerja Pegawai Untuk Kenaikan Jabatan Pegawai Menggunakan Metode Gap Kompetensi (Studi Kasus Perusahaan Perkasa Jaya Compuretail). Jurnal Sarjana Teknik Informatika, 1(2), 574-583.

[3] Sherly, N. (2013). Penerapan Metode Profile matching Dalam Sistem Pendukung Keputusan Pemberian Bonus Karyawan ( Studi Kasus : Pt . Sanghyang Seri Persero ). Sistem Pendukung Keputusan, 1(1), 42-47

[4] Sudarmadi, A., Santoso, E., \& Sutrisno. (2017). Sistem Pendukung Keputusan Pemilihan Personel Homeband Universitas Brawijaya Menggunakan Metode Profile matching. Jurnal Pengembangan Teknologi Informasi Dan Ilmu Komputer, 1(12), 1788-1796. Retrieved from www.j-ptiik.ub.ac.id.

[5] Li, Y., Zhuang, Y., Lan, H., Niu, X., \& El-Sheimy, N. (2016). A profilematching method for wireless positioning. IEEE Communications Letters, 20(12), 2514-2517. https://doi.org/10.1109/LCOMM.201 6.2608351 